\title{
Pembuatan Website Komunitas Parenting “Kampus Keluarga” sebagai Media Publikasi Informasi dan Edukasi Parenting
}

\author{
Safitri Juanita*1, Wahyu Pramusinto ${ }^{2}$, M. Anif ${ }^{3}$ \\ ${ }^{1}$ Program Studi Sistem Informasi, Fakultas Teknologi Informasi, Universitas Budi Luhur \\ ${ }^{2,3}$ Program Studi Teknik Informatika, Fakultas Teknologi Informasi, Universitas Budi Luhur \\ *Email Corresponding Authors: safitri.juanita@ budiluhur.ac.id ${ }^{1}$
}

\begin{abstract}
ABSTRAK
Komunitas Parenting "Kampus Keluarga" adalah salah satu komunitas parenting di Indonesia yang berlokasi di Kota Tangerang dan aktif memberikan informasi dan edukasi bagi para orang tua dan calon orang tua dengan cara mengadakan seminar, workshop dan pada masa pandemi Covid-19 melakukan kegiatan Webinar. Masalah pada mitra kegiatan pengabdian kepada masyarakat (PPM) adalah, saat ini Kampus Keluarga publikasi informasi dan edukasi parenting melalui media sosial Facebook dan Instagram namun belum memiliki banyak pengikut, dan adanya keterbatasan publikasi artikel edukasi, publikasi informasi profil serta kegiatan Kampus Keluarga dalam bentuk artikel melalui media sosial. Sehingga dibutuhkan media lain untuk membantu Kampus Keluarga publikasi artikel yang berkaitan dengan edukasi dan kegiatan komunitas parenting. Maka pada kegiatan PPM ini, TIM Dosen melakukan pembuatan Website Komunitas Parenting "Kampus Keluarga" dengan tujuan membantu untuk publikasi informasi kegiatan Kampus Keluarga serta menyebarkan artikel terkait edukasi parenting hingga dapat dijangkau oleh masyarakat luas. Kegiatan PPM menggunakan metode analisis kebutuhan mitra, menyewa hosting dan domain, instalasi dan konfigurasi CMS wordpress, sosialisasi dan pelatihan pengguna website. Evaluasi dari kegiatan PPM ini adalah, berdasarkan hasil kuesioner yang disebarkan ke pengurus kampus keluarga menyatakan 50\% setuju website menyajikan informasi sesuai dengan visi dan misi kampus keluarga, 66,7\% setuju website sangat mudah diakses, 50\% setuju website memberikan informasi yang relevan dan $50 \%$ setuju website memberikan informasi yang bermanfaat. Berdasarkan hasil evaluasi dapat disimpulkan bahwa kegiatan PPM yaitu pembuatan website komunitas "Kampus Keluarga" dapat membantu mitra dalam menyajikan informasi profil Kampus Keluarga, mudah diakses, memberikan informasi yang relevan dengan kegiatan Kampus Keluarga, serta memberikan informasi yang bermanfaat.
\end{abstract}

Kata kunci: Website Komunitas, Edukasi Parenting, Publikasi Informasi, Kampus Keluarga

\section{PENDAHULUAN}

Menurut (Sunarsih, Murti, Anantanyu, \& Wijaya, 2016) program parenting kurang diminati publik di Indonesia, sehingga solusinya adalah dengan membaca buku dan diskusi orang tua dan menurut (Kiling-Bunga, Margiani, \& Kiling, 2020) Praktik parenting yang kurang tepat memang belakangan ini sering disorot oleh banyak pemangku kepentingan seperti aktivis hak anak dan media. Melihat pentingnya praktik parenting saat ini sehingga memunculkan beberapa komunitas parenting yang hadir untuk membagi ilmu parenting dengan memanfaatkan sosial media seperti Instagram, Twitter dan Whatsapp grup dan semakin banyak seminar-seminar parenting yang diadakan untuk memberikan edukasi bagi orang tua dan calon orang tua dalam mengelola keluarga di era digital. Salah satu komunitas parenting adalah Kampus Keluarga yang berlokasi di Jl. H. Taufik No.3 Rt 02/08, Kelurahan Paninggilan Utara, Ciledug, Kota Tangerang. Kampus keluarga memiliki kegiatan seperti seminar atau Webinar 
dan Workshop dimana setiap kelas Workshop memiliki tenaga pengajar yang profesional di bidangnya. Komunitas ini memiliki media sosial Facebook dengan nama Kampus Keluarga dan instagram dengan id: Kampus.Keluarga_id namun kedua media sosial ini belum maksimal dalam menyebarkan informasi komunitas kampus keluarga seperti profil, visi dan misi kampus keluarga, penyebaran informasi kegiatan yang dilakukan oleh kampus keluarga serta artikel edukasi parenting. Masalah lainnya adalah komunitas ini tidak memiliki tenaga ahli untuk membuat website begitupun dana untuk membuatnya, sehingga dari masalah tersebut tim dosen dari Fakultas Teknologi Informasi, Universitas Budi Luhur bekerjasama dengan mitra pengabdian kepada masyarakat (PPM) Kampus Keluarga akan membuatkan website resmi komunitas parenting "Kampus Keluarga" yang bertujuan agar website tersebut dapat digunakan sebagai media publikasi informasi kegiatan komunitas serta media edukasi parenting bagi masyarakat dalam bentuk artikel, video, audio. Pada kegiatan ini akan diberikan pendampingan kepada mitra PPM dengan cara memberikan pelatihan tentang pengelolaan website kepada pengurus komunitas parenting "Kampus Keluarga" sehingga dapat memanfaatkan secara maksimal website bagi komunitas dan masyarakat luas. Pelatihan pengelolaan website sama seperti pelatihan CMS Content yang dilakukan oleh (Nasution \& Hasan, 2019). Gambar 1 adalah anggota komunitas parenting "Kampus Keluarga" dan gambar 2 adalah salah satu seminar parenting yang diadakan oleh komunitas parenting "Kampus Keluarga".

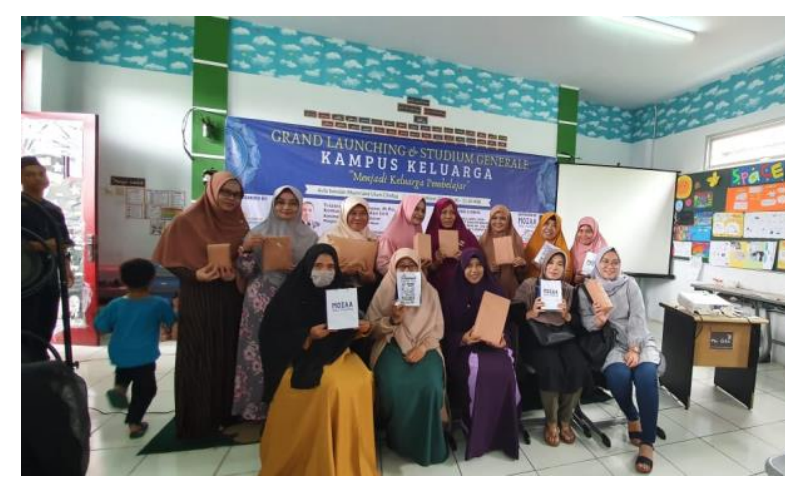

Gambar 1. Anggota parenting "Kampus Keluarga"

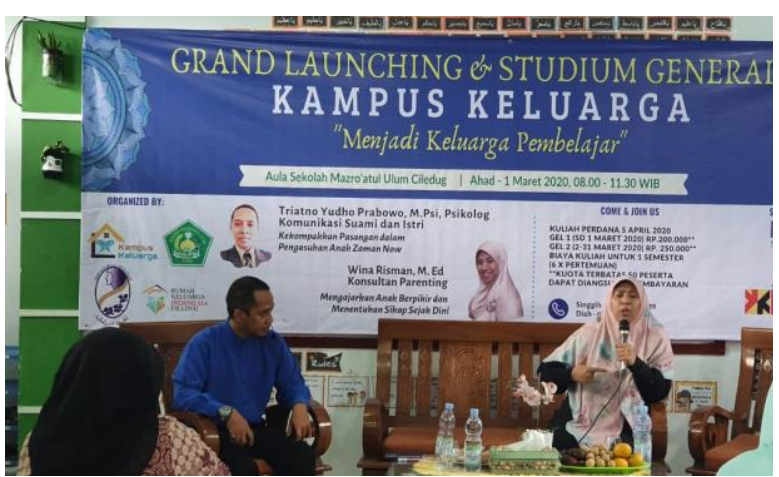

Gambar 2. Seminar Parenting yang diadakan Kampus Keluarga

Manfaat pembuatan website bagi komunitas bisa dilihat dari beberapa publikasi ilmiah yang telah dilakukan sebelumnya, berikut ini adalah kumpulan publikasi ilmiah yang berkaitan dengan manfaat pembuatan website bagi komunitas dan organisasi masyarakat yang dirangkum dalam bentuk literatur review pada tabel 1.

Tabel 1. Studi Literatur

\begin{tabular}{|c|c|c|c|}
\hline Judul & Masalah & Metode & Kesimpulan \\
\hline $\begin{array}{l}\text { Website } \\
\text { Informasi } \\
\text { Komunitas Di } \\
\text { Kota Malang } \\
\text { (Perkasa \& } \\
\text { Iriananda, 2017) }\end{array}$ & $\begin{array}{l}\text { Tidak ada wadah yang } \\
\text { menaungi komunitas di } \\
\text { Malang sehingga } \\
\text { membingungkan } \\
\text { masyarakat di kota Malang } \\
\text { yang ingin bergabung } \\
\text { dengan komunitas tersebut }\end{array}$ & $\begin{array}{l}\text { Website } \\
\text { dibangun } \\
\text { menggunaka } \\
\mathrm{n} \text { bahasa } \\
\text { pemrograman } \\
\text { PHP dan } \\
\text { MySQL }\end{array}$ & $\begin{array}{l}\text { Website menjadi wadah } \\
\text { untuk semua komunitas } \\
\text { yang ada di Kota Malang } \\
\text { sehingga memudahkan } \\
\text { masyarakat memperoleh } \\
\text { informasi mengenai } \\
\text { komunitas di Malang serta } \\
\text { website menjadi sumber } \\
\text { informasi untuk anggota }\end{array}$ \\
\hline
\end{tabular}




\begin{tabular}{|c|c|c|c|}
\hline 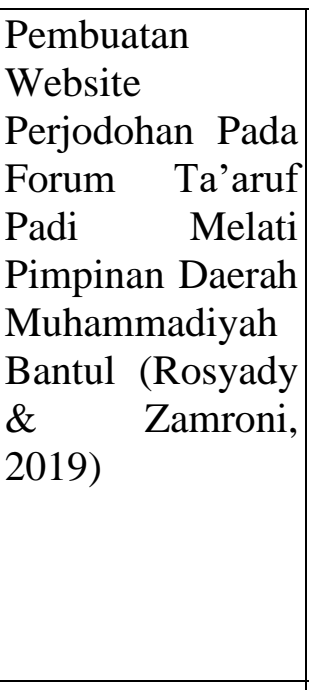 & $\begin{array}{lr}\text { Proses pendataan } & \text { biodata } \\
\text { pihak yang } & \text { akan } \\
\text { dijodohkan } & \text { masih } \\
\text { dilakukan secara } & \text { manual } \\
\text { dengan Google } & \text { Form dan } \\
\text { Whatsapp. } & \text { Sehingga } \\
\text { dibutuhkan sebuah sistem } & \text { sem } \\
\text { yang bisa } & \text { membantu } \\
\text { melakukan } & \text { matching } \\
\text { secara efektif dan efisien } \\
\text { dengan r menggunakan } \\
\text { database yang terpusat dan } \\
\text { terkategorisasi dengan baik }\end{array}$ & $\begin{array}{l}\text { Survey ke } \\
\text { pihak mitra, } \\
\text { pembuatan } \\
\text { dan } \\
\text { pengembanga } \\
\text { n website, } \\
\text { dan uji coba } \\
\text { website }\end{array}$ & $\begin{array}{l}\text { Berhasil dibangun sistem } \\
\text { website perjodohan dengan } \\
\text { basis data yang tersentral } \\
\text { menggunakan webform } \\
\text { dengan fitur dari google } \\
\text { form. Melalui sistem ini, } \\
\text { proses taaruf akan lebih } \\
\text { informatif dan bisa diakses } \\
\text { oleh siapapun serta proses } \\
\text { perjodohan akan lebih } \\
\text { mudah, efektif, dan efisien } \\
\text { karena bisa ditayangkan } \\
\text { dalam satu file basis data } \\
\text { terpusat }\end{array}$ \\
\hline $\begin{array}{l}\text { Model } \\
\text { Pengembangan } \\
\text { Web Komunitas } \\
\text { untuk } \\
\text { Mendukung } \\
\text { Proses } \\
\text { Interactive } \\
\text { Distance } \\
\text { Learning (Daru } \\
\& \text { Adhiwibowo, } \\
\text { 2017) }\end{array}$ & $\begin{array}{l}\text { Kebutuhan bagi proses } \\
\text { pembelajaran } \\
\text { dimana siswa dan guru } \\
\text { harus berkomunikasi maka } \\
\text { penelitian ini membuat } \\
\text { sebuah web komunitas } \\
\text { dengan menambahkan } \\
\text { beberapa fasilitas seperti } \\
\text { Private Chat, Public Chat, } \\
\text { Forum dan video sharing } \\
\text { akan dapat dijadikan } \\
\text { sebagai sarana proses } \\
\text { pembelajaran }\end{array}$ & $\begin{array}{l}\text { Mengembang } \\
\text { ankan web } \\
\text { berbasis } \\
\text { komunitas } \\
\text { sebagai } \\
\text { pendukung } \\
\text { proses } \\
\text { Interactive } \\
\text { Distance } \\
\text { Learning }\end{array}$ & $\begin{array}{l}\text { Terbentuknya } r \text { web } \\
\text { komunitas yang dapat } \\
\text { dimanfaatkan sebagai } \\
\text { sarana saling berbagi } \\
\text { informasi, diskusi dan } \\
\text { tempat penyampaian } \\
\text { materi secara online, } \\
\text { sehingga proses belajar } \\
\text { dapat dilakuan setiap saat }\end{array}$ \\
\hline $\begin{array}{l}\text { Pembuatan dan } \\
\text { Pelatihan } \\
\text { Pengelolaan } \\
\text { Website serta } \\
\text { Email Resmi } \\
\text { untuk Organisasi } \\
\text { Pemuda Peduli } \\
\text { Lingkungan Bali } \\
\text { (PPLB) } \\
\text { Kabupaten } \\
\text { Buleleng" } \\
\text { (Pradnyana, } \\
\text { Arthana, } \\
\text { Putrama, } \\
\text { Pradnyana, \& } \\
\text { Sindu, 2017) }\end{array}$ & 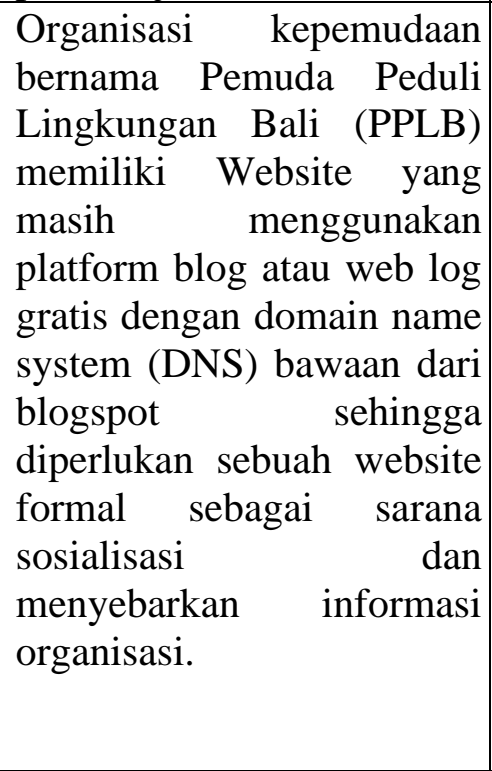 & $\begin{array}{l}\text { Tahapannya } \\
\text { adalah } \\
\text { Pembuatan } \\
\text { website dan } \\
\text { email } \\
\text { selanjutnya } \\
\text { pelatihan } \\
\text { pengelolaan } \\
\text { serta } \\
\text { pemanfaatan } \\
\text { website dan } \\
\text { email tersebut }\end{array}$ & $\begin{array}{l}\text { Kualitas dari website yang } \\
\text { dibangun sudah sangat baik. } \\
\text { Akan tetapi, pada } \\
\text { kelengkapan informasi } \\
\text { mendapatkan point yang } \\
\text { lebih rendah dibandingkan } \\
\text { yang lainnya, mengingat } \\
\text { konten yang tercantum } \\
\text { dalam website belum terlalu } \\
\text { lengkap. }\end{array}$ \\
\hline $\begin{array}{l}\text { Pembuatan } \\
\text { Website untuk } \\
\text { Komunitas } \\
\text { PPKM } \\
\text { (Sahertian, } \\
\text { Setiabudi, \& } \\
\text { Santoso, 2017) }\end{array}$ & $\begin{array}{l}\text { Karena banyaknya anggota } \\
\text { yang tersebar di Indonesia, } \\
\text { hal ini menyebabkan } \\
\text { kesulitan dalam } \\
\text { berkomunikasi. }\end{array}$ & $\begin{array}{l}\text { Pembuatan } \\
\text { Website } \\
\text { menggunakan } \\
\text { notepad++, } \\
\text { XAMPP dan } \\
\text { browser, } \\
\text { HTML, CSS3, }\end{array}$ & $\begin{array}{l}\text { berhasil di buat Sebuah } \\
\text { website yang digunakan } \\
\text { sebagai media berita, } \\
\text { informasi dan komunikasi } \\
\text { seputar komunitas dan telah } \\
\text { melalui pengujian terhadap } \\
\text { fitur-fitur yang ada pada }\end{array}$ \\
\hline
\end{tabular}




\begin{tabular}{|c|c|c|c|}
\hline & 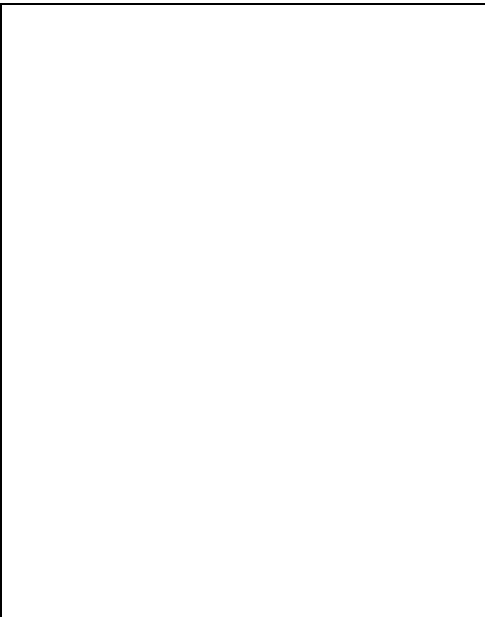 & $\begin{array}{l}\text { PHP, dan } \\
\text { MySQL untuk } \\
\text { membuat } \\
\text { database, serta } \\
\text { menggunakan } \\
\text { Instagram API } \\
\text { untuk } \\
\text { mengintegrasi } \\
\text { kan foto-foto } \\
\text { pada media } \\
\text { sosial } \\
\text { Instagram ke } \\
\text { dalam website }\end{array}$ & website ini \\
\hline
\end{tabular}

Berdasarkan literatur review publikasi ilmiah di atas maka dapat disimpulkan bahwa pembuatan website sebagai media publikasi bagi komunitas maupun organisasi memberikan manfaat bagi komunitas dalam menyebarkan informasi bagi masyarakat luas terutama bagi anggota komunitas karena memberikan kemudahan dalam mendapatkan informasi tanpa mengenal jarak dan waktu, sebagai media penyampaian informasi up to date, efektif dan efisien karena jangkauan penyebaran lebih luas. Mengapa penting penyebaran edukasi parenting secara digital di masyarakat?menurut penelitian yang dilakukan oleh (Rahmat, 2018) Orang tua yang hebat harus terlibat dalam mendidik anak dengan pola asuh yang demokratis, positif, efektif, konstruktif dan transformatif. dan menurut (Laely, Istiningsih, Pramita, \& Iftitah, 2017) masyarakat menyadari betapa pentingnya pengasuhan yang diberikan orang tua. Bahwasannya sekarang sudah masuk dalam Era Digital yang segala sesuatu informasi dapat dengan mudah kita dapatkan melalui internet. 


\section{METODE}

Metode Pelaksanaan Kegiatan Pengabdian Kepada Masyarakat (PPM) yang dilakukan selama 4 bulan (April 2020 - Agustus 2020) mulai dari persiapan hingga laporan kegiatan akan ditampilkan pada gambar 3 .

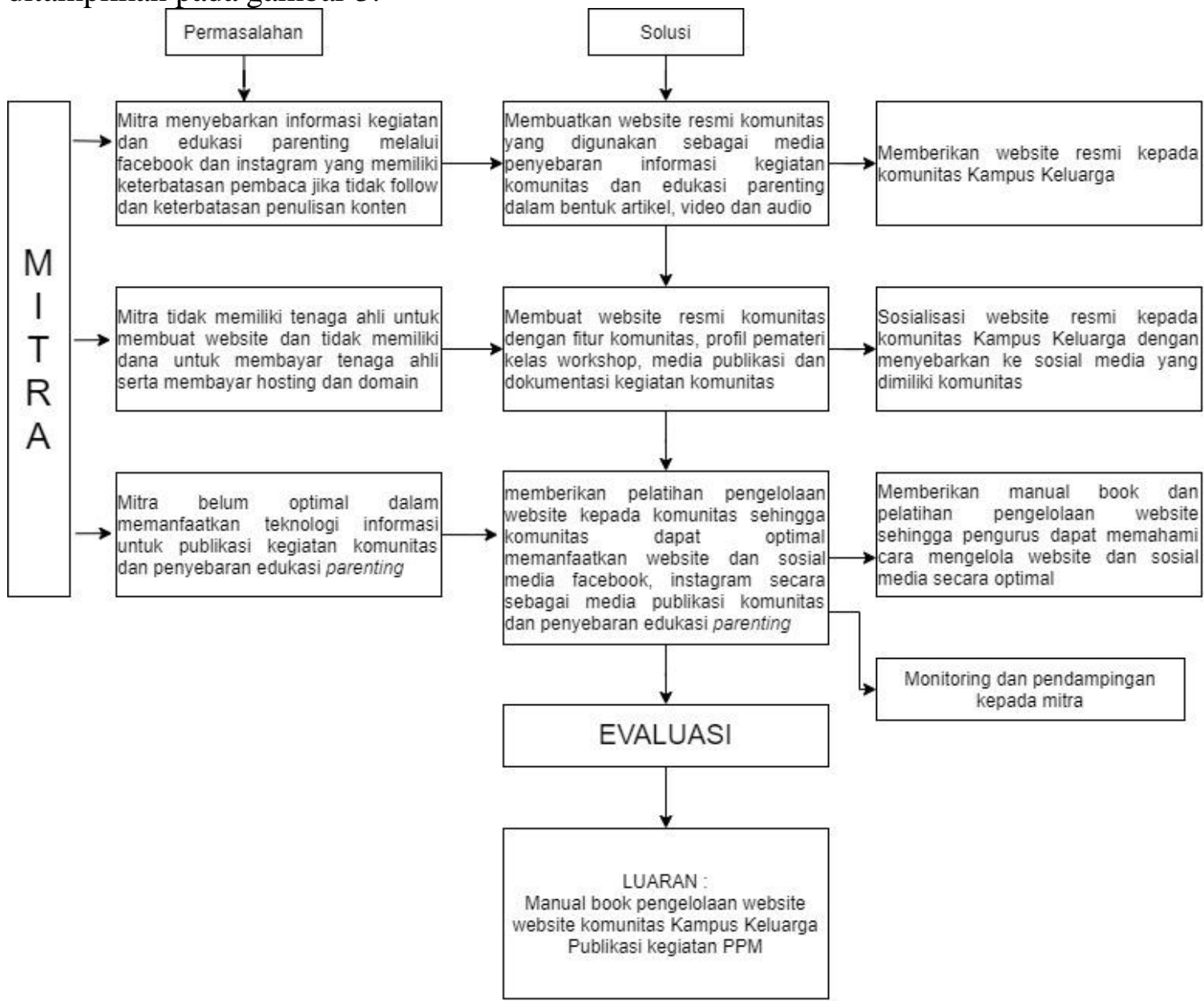

Gambar 3. Metode Pelaksanaan Kegiatan Pengabdian Kepada Masyarakat

\section{Road Map Pengabdian kepada Masyarakat}

Pada tabel 2 adalah road map kegiatan pengabdian kepada masyarakat yang dilakukan oleh tim dosen Fakultas Teknologi Informasi (FTI), Universitas Budi Luhur bersama mitra Kampus Keluarga.

Tabel 2. Road Map Pengabdian Kepada Masyarakat

\begin{tabular}{|c|l|l|l|}
\hline No & Waktu Kegiatan & \multicolumn{1}{|c|}{ Uraian Kegiatan } & \multicolumn{1}{c|}{ Hasil } \\
\hline 1 & April 2020 & $\begin{array}{l}\text { Pertemuan dengan mitra dan } \\
\text { diskusi tentang permasalahan } \\
\text { yang dimiliki mitra }\end{array}$ & $\begin{array}{l}\text { Surat Pernyataan Kesediaan } \\
\text { Kerjasama }\end{array}$ \\
\hline 2 & Mei - Juli 2020 & $\begin{array}{l}\text { Pengumpulan data, analisis } \\
\text { kebutuhan, desain, pembelian } \\
\text { domain dan hosting, instalasi } \\
\text { CMS Wordpress, Konfigurasi }\end{array}$ & $\begin{array}{l}\text { Terwujudnya Website } \\
\text { Kampus Keluarga di } \\
\text { Www.kampuskeluarga.com } \\
\text { Website, User Acceptance } \\
\text { Test (UAT) ke pengurus } \\
\text { Kampus Keluarga }\end{array}$ \\
\end{tabular}




\begin{tabular}{|c|l|l|l|}
\hline 3 & Agustus 2020 & $\begin{array}{l}\text { Sosialisasi dan pelatihan } \\
\text { pengelolaan website Kampus } \\
\text { Keluarga }\end{array}$ & $\begin{array}{l}\text { Ketua dan Pengurus Kampus } \\
\text { keluarga terutama Humas } \\
\text { Kampus Keluarga memahami } \\
\text { cara mengoperasikan website }\end{array}$ \\
\hline
\end{tabular}

\section{HASIL DAN PEMBAHASAN}

\section{Tampilan Website}

Website Kampus Keluarga dapat diakses di http://kampuskeluarga.com/. Pada gambar 4 adalah tampilan halaman depan website kampus keluarga terdapat menu Home, Profil, Kegiatan, Kutipan Hikmah dan artikel parenting. Pada halaman depan (menu Home) terdapat header berupa gambar Grand Launching Kampus Keluarga, logo Kampus keluarga, Visi dan Misi Kampus Keluarga serta kumpulan foto kegiatan

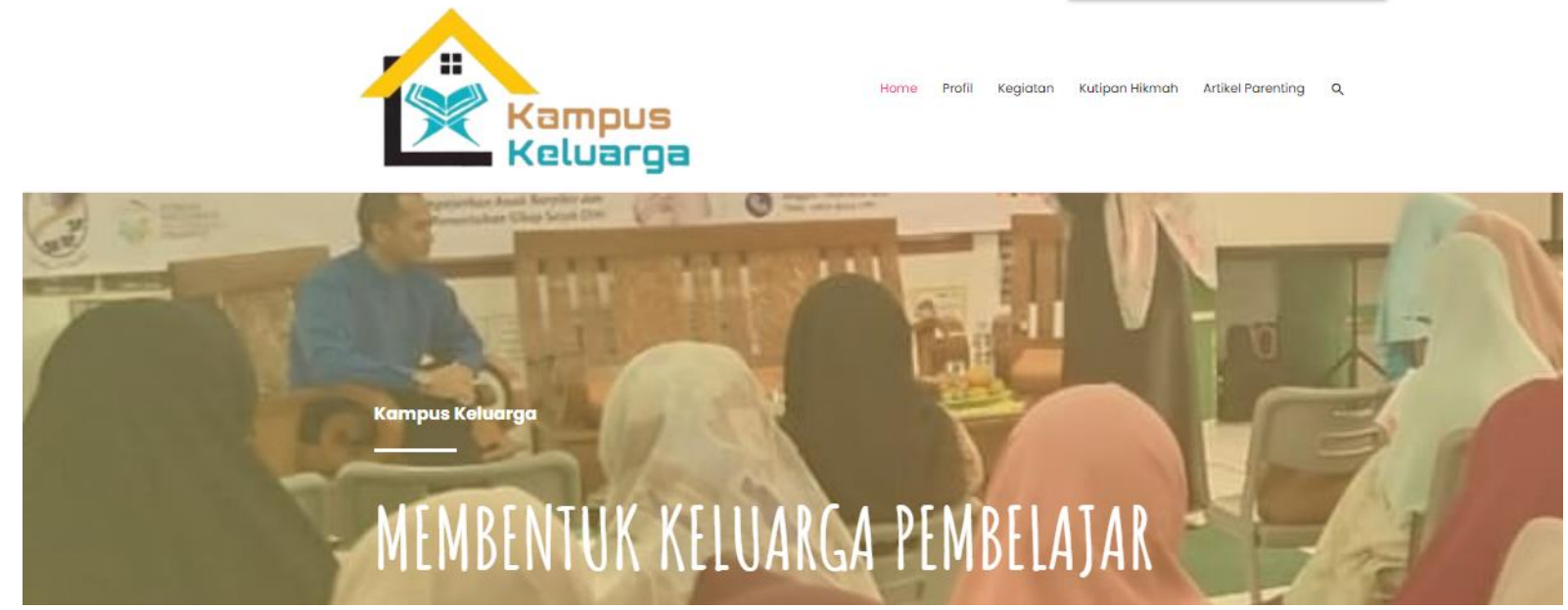

Gambar 4. Halaman Depan Website Kampus Keluarga

Karena kondisi pandemi CORONA-19 dimulai dari bulan Maret hingga saat ini bulan Agustus 2020 di kota Tangerang dan Jakarta masih diberlakukan Pembatasan Sosial Berskala Besar (PSBB) sehingga Pelaksanaan sosialisasi website dan training pengguna yang ingin dilakukan secara tatap muka direalisasikan menjadi online menggunakan Zoom Meeting, namun tidak semua pengurus komunitas parenting Kampus Keluarga ikut serta saat training penggunaan website. Pada gambar 5 adalah dokumentasi kegiatan saat pembukaan dan sosialisasi tentang pembuatan website komunitas parenting "Kampus Keluarga" yang dilakukan secara daring. Pada gambar 6 adalah dokumentasi kegiatan pelatihan pengelolaan website komunitas parenting "Kampus Keluarga" yang dilakukan secara daring. 


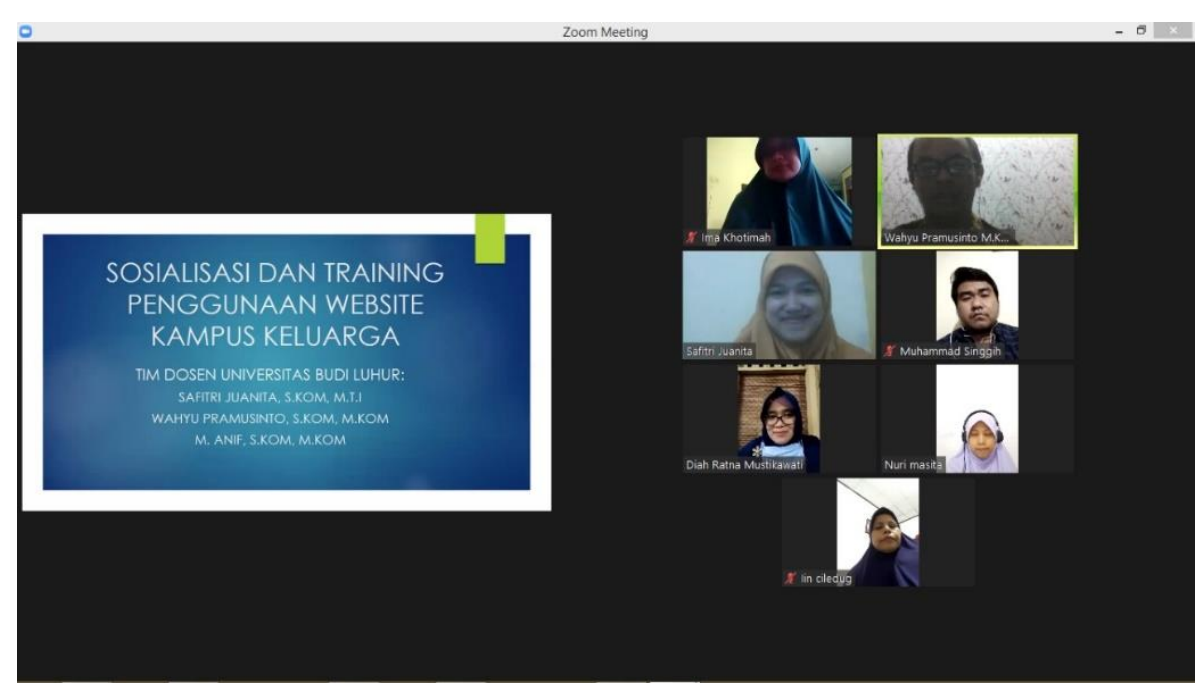

Gambar 5. Sosialisasi Website Komunitas Parenting "Kampus Keluarga"

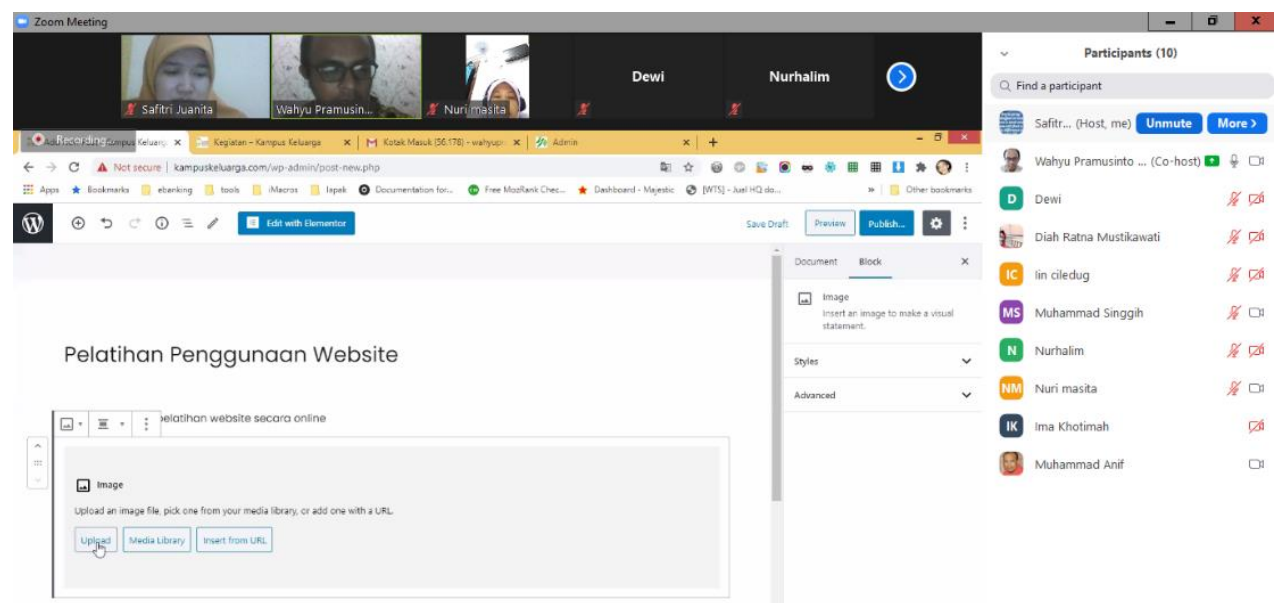

Gambar 6. Pelatihan Pengelolaan Website Komunitas Parenting "Kampus Keluarga"

\section{Evaluasi kegiatan}

Pada kegiatan sosialisasi dan pelatihan penggunaan website Kampus Keluarga, kami memberikan kuesioner kepada pengurus Kampus Keluarga untuk menilai website Kampus Keluarga yang telah dibuat oleh tim Dosen FTI. Kuesioner yang digunakan bersifat tertutup yaitu angket yang sudah disediakan jawabannya. Berikut ini adalah hasil kuesioner yang terkumpul:

\section{Website Menyajikan Informasi Sesuai dengan Visi Dan Misi Kampus Keluarga}

Berdasarkan hasil kuesioner yang dilakukan untuk mengetahui apakah pengguna menganggap website menyajikan informasi sesuai dengan visi dan misi Kampus Keluarga maka berdasarkan gambar 7 terdapat 50\% pengguna menyatakan setuju, $16.7 \%$ pengguna menyatakan cukup setuju, dan $33.3 \%$ pengguna menyatakan sangat setuju. 


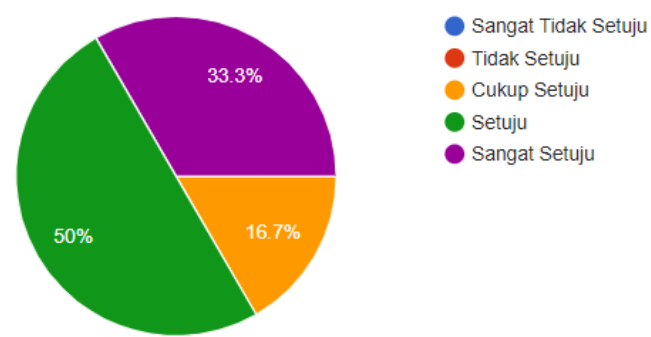

Gambar 7. Hasil Kuesioner Website Menyajikan Informasi sesuai dengan Visi dan Misi Kampus Keluarga

\section{Website Menyediakan Informasi Yang Relevan}

Berdasarkan hasil kuesioner yang dilakukan untuk mengetahui apakah pengguna menganggap website menyediakan informasi yang relevan maka berdasarkan gambar 8 terdapat $50 \%$ pengguna menyatakan setuju, $16.7 \%$ pengguna menyatakan sangat setuju, dan $33.3 \%$ pengguna menyatakan cukup setuju.

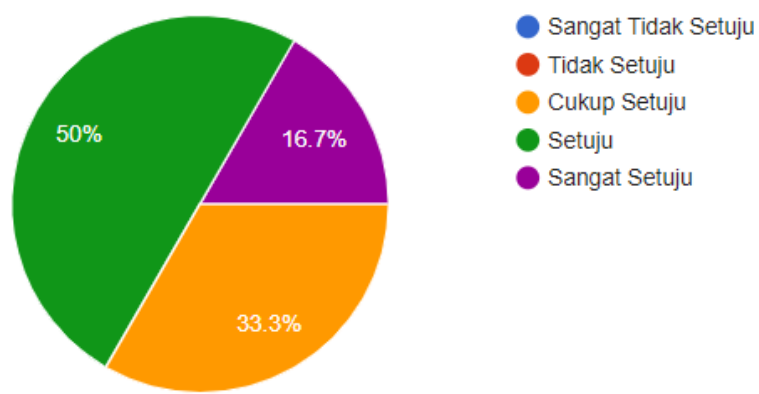

Gambar 8. Hasil Kuesioner Website menyediakan informasi yang relevan

\section{Website Kampus Keluarga Memberikan Informasi yang bermanfaat}

Berdasarkan hasil kuesioner yang dilakukan untuk mengetahui apakah menurut pengguna website Kampus Keluarga memberikan informasi yang bermanfaat maka berdasarkan gambar 9 terdapat $50 \%$ pengguna menyatakan setuju, 33.3\% pengguna menyatakan sangat setuju, dan $16.7 \%$ pengguna menyatakan cukup setuju.

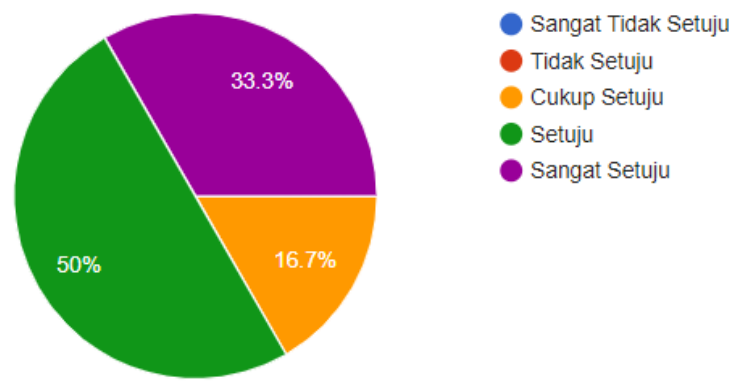

Gambar 9. Website Kampus Keluarga Memberikan Informasi Yang Bermanfaat

\section{KESIMPULAN}

Berdasarkan pelaksanaan pengabdian kepada masyarakat yang telah dilakukan maka diperoleh kesimpulan sebagai berikut:

1. Implementasi website sebagai media publikasi informasi dan edukasi parenting pada Komunitas parenting "Kampus Keluarga" berjalan dengan baik, karena berdasarkan hasil kuesioner dari pengurus kampus keluarga menyatakan bahwa 50\% setuju website menyajikan informasi sesuai dengan visi dan misi kampus keluarga, 66,7\% setuju 
website sangat mudah diakses, $50 \%$ setuju website memberikan informasi yang relevan, $66,7 \%$ setuju website mengandung kompetensi, 66,7 setuju website memiliki tampilan yang menarik dan $50 \%$ setuju website memberikan informasi yang bermanfaat.

2. Website telah dibuat sesuai dengan kebutuhan mitra PPM yaitu Kampus Keluarga.

3. Pengurus Kampus Keluarga telah memiliki kemampuan dalam membuat artikel atau publikasi kegiatan yang dipublish ke website Kampus Keluarga.

\section{UCAPAN TERIMA KASIH}

Penulis mengucapkan terima kasih kepada Universitas Budi Luhur yang telah memberikan dukungan financial kepada penulis dalam pelaksanaan program pengabdian kepada masyarakat ini. dan terima kasih kepada komunitas parenting "Kampus Keluarga" yang sudah membantu terlaksananya kegiatan ini.

\section{DAFTAR PUSTAKA}

Daru, A. F., \& Adhiwibowo, W. (2017). Model Pengembangan Web Komunitas untuk Mendukung Proses Interactive Distance Learning. Jurnal Informatika Upgris, 2(2). https://doi.org/10.26877/jiu.v2i2.1189

Kiling-Bunga, B. N., Margiani, K., \& Kiling, I. Y. (2020). Perkembangan penelitian parenting di Indonesia. Retrieved from

https://www.researchgate.net/publication/338789178_Perkembangan_penelitian_parenting _di_Indonesia

Laely, K., Istiningsih, G., Pramita, Y. D., \& Iftitah, N. (2017). Parenting Pengasuhan di Era Digital dalam Rangka Mendukung Terwujudnya PKBM ( Pusat Kegiatan Belajar Masyarakat ) di Daerah Miskin. In The 6th University Research Colloquium 2017 (Urecol) (pp. 1-8). Universitas Muhammadiyah Magelang.

Nasution, N., \& Hasan, M. A. (2019). IBM Pelatihan CMS Content dan Digital Jurnalistik. Dinamisia : Jurnal Pengabdian Kepada Masyarakat, 3(1), 22-30. https://doi.org/10.31849/dinamisia.v3i1.1482

Perkasa, B. S., \& Iriananda, S. W. (2017). Website Informasi Komunitas Di Kota Malang. Jurnal Informatika Merdeka Pasuruan, 2(1), 44-53. https://doi.org/10.37438/jimp.v2i1.52

Pradnyana, G. A., Arthana, K. R., Putrama, I. M., Pradnyana, I. M. A., \& Sindu, I. G. P. (2017). Pembuatan dan Pelatihan Pengelolaan Website serta Email Resmi untuk Organisasi Pemuda Peduli Lingkungan Bali (PPLB) Kabupaten Buleleng. In Prosiding Seminar Nasional Pengabdian kepada Masyarakat (SENADIMAS) 2 (pp. 134-143). Retrieved from http://pplingkunganbali.blogspot.co.id/.

Rahmat, S. T. (2018). Pola Asuh Yang Efektif Untuk Mendidik Anak di Era Digital. Jurnal Pendidikan Dan Kebudayaan Missio, 10(2), 137-273.

Rosyady, P. A., \& Zamroni, G. M. (2019). Pembuatan website perjodohan pada forum ta'aruf padi melati Pimpinan Daerah Muhammadiyah Bantul. In Seminar Nasional Hasil Pengabdian Kepada Masyarakat Universitas Ahmad Dahlan (pp. 725-732). Yogyakarta: Universitas Ahmad Dahlan.

Sahertian, K. A., Setiabudi, D. H., \& Santoso, L. W. (2017). Pembuatan Website untuk Komunitas PPKM. Jurnal Infra, 5(1), 3-7.

Sunarsih, T., Murti, B., Anantanyu, S., \& Wijaya, M. (2016). Path Analysis: Health Promotion Information Access of Parent Caretaking Pattern through Parenting Education. International Journal of Evaluation and Research in Education (IJERE), 5(1), 69. https://doi.org/10.11591/ijere.v5i1.4524 